\title{
Brazil
}

\section{"Unconstitutionality of Patent Extensions"}

\section{Decision of the Supreme Federal Court of Brazil (Supremo Tribunal Federal)} 12 May 2021 - Case No. 672/2020

\section{Law No. 9.279/1996 (IPA), Art. 40; Federal}

Constitution, Art. 5 (LXXVIII and XXIX), Art. 37 and 170

Keywords Social function of intellectual property - Fundamental right to health Period of validity - Date of filing vs. date of granting - Infringement of legal certainty $\cdot$ Ex nunc effects

1. The sole paragraph of Art. 40 of the Brazilian Intellectual Property Act (Law No. 9279/1996) is unconstitutional.

2. This decision has ex nunc effects.

3. Exempted from the ex nunc effects - with only ex tunc effects - are (i) the judicial actions filed by or on 7 April 2021 (date of the partial upholding of the preliminary injunction in the present case), and (ii) the patents granted with an extension of the term related to pharmaceutical products and processes, as well as healthcare devices and/or materials.

\section{Summary:}

Direct action for a declaration of unconstitutionality. Sole paragraph of Art. 40 of Law No. 9.279/1996. Industrial Property Act. Extension of the period of validity of patents in the event of an administrative delay in the examination of the application. Indeterminacy of the period of validity of the exclusive right to use the invention. Infringement of legal certainty, of the timeliness of the patent, of the social function of intellectual property, of a reasonable duration of the proceedings, of the

Translated from the Portuguese by ÜZM GmbH, Munich, Germany. This is a translation of an edited summary of the decision.

For a case note on this decision by Mário André Machado Cabral, "Automatic Patent Term Extensions Ruled Unconstitutional in Brazil: Better Late Than Never?" see this issue of IIC at https://doi.org/10. 1007/s40319-021-01145-8. 
efficiency of public administration, of free competition, of consumer protection, and of the right to health. Application upheld. Modulation of the effects of the judgment.

1. The protection of industrial property, which is enshrined as a fundamental right in Art. 5(XXIX) of the 1988 Constitution, is limited in time and based on the social interest and the technological and economic development. It is therefore an institution with a constitutionally determined objective, and is not limited to an individual right, as it concerns the society and the development of the Country.

2. According to Art. 40, caput $^{1}$ of Law No. 9279/1996, the period of validity of a patent is 20 (twenty) years for inventions, and 15 (fifteen) years for utility models, calculated from the date of the filing. The Brazilian Intellectual Property Act (IPA) provides for an additional rule in the sole paragraph of the provision: From the date of the granting of the patent, the period of validity may not be less than 10 (ten) years for an invention patent and 7 (seven) years for a utility model patent. Therefore, we can deduce from Art. 40 the significance of two time limits for determining the period of validity of patents: the date of the filing and the date of the granting of the patent.

3. The sole paragraph of Art. 40 establishes a variable term of protection, since this depends on the processing time of the respective administrative procedure at the National Institute of Industrial Property (INPI). Thus, if the authority needs more than 10 (ten) years in the case of an invention or more than 8 (eight) years in the case of a utility model to take a final decision, the entire benefit period will exceed the period of validity provided for in Art. 40, caput.

4. The sole paragraph of Art. 40 of the IPA is said to have been introduced with the aim of compensating for the backlog of patent applications (backlog) at the INPI. This phenomenon has existed since the adoption of Law No. 9279/1996, with which, in alignment with the Agreement on Trade-Related Aspects of Intellectual Property Rights (TRIPS Agreement), certain products that were previously not subject to exclusive use were made patentable. Following the implementation of the [TRIPS] Agreement and the adoption of Law No. 9.279/1996 without recourse to the transitional period granted to the developing countries, the federal authorities were unable to cope with the additional burden of new registered products, resulting in a large backlog of applications.

5. Article 33 of the TRIPS Agreement guarantees that the patent will be valid for at least 20 years from the date of filing of the application. The rationale of the [TRIPS] Agreement is that the mere filing creates a presumption in favour of applicant. The additional period of validity from the date of the granting of the patent which is set out in the sole paragraph of Art. 40 therefore does not follow from the TRIPS Agreement, nor does it find a parallel in other jurisdictions where the additional exclusive rights follow a logic which is substantially different from that of Brazilian law, since those have a limited application, are limited to certain cases, and do not constitute automatic rights. The instruments that are adopted abroad to extend the

\footnotetext{
${ }^{1}$ Editor's Note: In Brazilian legislation "caput" ("head" in Latin) is the main section of an Article when it contains subsections or paragraphs. The "caput" contains the primary statement.
} 
exclusive useful life of inventions - in their various forms, durations, and specific rules - contain mechanisms that prevent the validity of the patent from being extended longer than necessary.

6. The sole paragraph of Art. 40 is inappropriate in several respects, since it has the effect of making the period of validity of patents indefinite. The final period of validity of a patent in Brazil is only known from the date of the actual granting of the patent, which can take more than ten years. In practice, this has the consequence that there is no time limit on patent protection in Brazil, leading to the absurd scenario where patents are in force in the country for extremely long periods of time - around 30 years - which exceeds the limits of reason, and which brings the country into conflict in the field of intellectual property law with respect to other jurisdictions.

7. As long as the sole paragraph of Art. 40 is in force, the period between the filing and the granting of a patent will always be indefinite, with or without a backlog at the INPI. This is because the processing time of the Patent Office is an indefinite factor, given the complexity which is associated with the analysis of this type of filing - which is variable and depends on the product and the corresponding technological sector - as well as the complications which may occur during the administrative procedure - some of which are brought on by the applicants themselves in order to benefit from the automatic renewal which is provided for in the rule in question. Even if the INPI overcame the chronic delay in examining patent applications, the unconstitutionality of the sole paragraph of Art. 40 would remain.

8. The extension of the period of validity of the patent, which is provided for in the IPA, not only does not contribute in any way to resolving the chronic backlog of applications which are submitted to the INPI, but also leads to non-compliance with the time limits laid down in Art. 40, caput, since it reduces the consequences of the administrative delay and extends the benefit period for the respective applicants to the disadvantage of other market participants, the public administration, and society as a whole. There is sufficient evidence in the files to suggest that the contested provision increases the backlog, and thus virtually contributes to the emergence of the phenomenon which it seeks to prevent, which constitutes a direct breach of the principles of reasonable duration of proceedings (Art. 5, LXXVIII, Federal Constitution) and administrative efficiency (Art. 37, caput, Federal Constitution).

9. The effects of an extension of the period of validity of a patent on the [Brazilian public] unified health system deserve attention, as this, being one of the largest public health systems in the world and including a network of services aimed at making access to free healthcare universal, requires public funds compatible with the scope and complexity of the system, which, however, encounter financial and budgetary problems typical of a developing country such as Brazil. The commercial dominance provided by the patent over very long periods of time affects the population's access to public health services, as it puts a strain on the system, namely by eliminating competition and by imposing the purchase of pharmaceutical 
products for a price unilaterally set by the rights owner and increased by the payment of royalties, which are purchased and distributed by the public authorities.

10. The longer the exclusivity period for the holder of the pharmaceutical patent, the greater the burden will be on the public sector and on society, bearing in mind that medicines must be procured on a large scale for the implementation of public health policy. This connection becomes even more serious and urgent in light of the international health emergency resulting from the Covid-19 pandemic. Coping with a crisis of such magnitude requires the management of scarce resources of various kinds, not only those associated with the purchase of medicines with possible indications for the treatment of the disease. Pressure on the healthcare system has increased worldwide, thus increasing the demand for inputs across the whole supply chain.

11. The undue extension of the period of validity of pharmaceutical patents is unjust and unconstitutional, since it privileges private interests to the disadvantage of the community, has an extreme impact on the provision of public health services in the country and, consequently, violates the constitutional right to health (Art. 196 of the 1988 Constitution). The extension of the validity of patents has a direct impact on the country's public health policy and hinders citizens' access to medicines, healthcare measures and services, harming not only competitors and consumers, but above all those who depend on the unified health system to ensure their physical well-being and survival.

12. The vagueness of the period of validity which is laid down in the sole paragraph of Art. 40 of Law No. 9.279/1996 creates legal uncertainty and violates the democratic state governed by the rule of law itself. The predictability of the validity of patents is an essential condition for market participants (applicants, potential competitors and investors) to be able to take rational decisions. The absence of clear rules also leaves room for discretion and the opportunistic and unconventional application of the rules of the game, such as, for example, the strategies used by applicants for the extension of the exclusive right to exploit the products.

13. The time limit which is provided for in Art. 5, Sec. XXIX of CF/88 (Federal Constitution) must be interpreted in the light of the scope of patent protection, which is not limited to the protection of the interests of inventors/patent applicants, but also ensures the use of the invention by society as a whole (i) on the basis of clear rules, and (ii) for a reasonable period of time. Thus, the competitive advantage which is granted to the creators of inventions or utility models should have a specific and foreseeable duration so that not only the beneficiaries but also the other players in the industry can accurately assess the time of the expiry of the period of validity of a patent. In this sense, the contested provision does not comply with the requirement of temporality, since, by linking the validity of the patent to the date of its grant, i.e. indirectly to the time taken by the respective procedure at the INPI, the period of validity of the benefit becomes indefinite, which contributes to the extrapolation of the time limits laid down in Art. 40, caput of the IPA and to a lack of objectiveness and predictability of the whole procedure 
14. A time limit of the patent makes it possible to reconcile the protection of inventions with the fulfilment of the social function of property, since, although it protects the rights of inventors of inventions or utility models for a certain period of time and encourages and remunerates investment in innovation, it guarantees to the rest of the industry and, ultimately, society, the possibility of reaping the benefits of the results of creativity as soon as the rights to use them expire.

15. The sole paragraph of Art. 40 of the IPA permits the postponement of the market entry of competitors and favors the permanence of exclusivity effects for an indefinite and excessive duration, which promotes market dominance, allows the elimination of competition and the arbitrary increase of profits, deepens inequality between economic operators, and transforms what would be justified and reasonable unconstitutional, thus configurating an infringement of the social function of intellectual property (Art. 5, clause XXIX, c/c, Art. 170, clause III), of free competition, and of consumer protection (Art. 170, clauses IV and V).

16. The delay in the examination of patents is a reality that must be combated in order to ensure legal certainty for all market participants. Nothing justifies an administrative examination period of around ten years. I appeal to the Federal Public Administrator (the National Institute of Industrial Property, the National Health Surveillance Agency, and the Secretary of Science, Technology, and Strategic Inputs of the Ministry of Health) to make effective efforts to remedy the shortcomings in the examination of patent applications.

17. The direct action is upheld and the sole paragraph of Art. 40 of Law No. 9.279/1996 is declared unconstitutional.

18. Modulation of effects of the decision by granting effects ex nunc from the publication of the text of the present judgment in order to maintain the extensions of time limits granted on the basis of that statutory provision, and thus to ensure the validity of the patents already granted and still in force by virtue of the application of that statutory provision. Excluded from the modulation are: (i) the judicial actions which were filed by 7 April 2021 (the date of the partial upholding of the preliminary injunction in the present case), and (ii) the patents granted with an extension of the term related to pharmaceutical products and processes, as well as healthcare devices and/or materials. In both of these situations the ex tunc effect is applicable, which will result in the loss of the extensions of the period of validity granted on the basis of the sole paragraph of Art. 40 of the IPA; the period of validity of patents, laid down in Art. 40, caput of Law No. 9.279/1996, must be respected and any concrete effects already arising from the extension of the period of validity of said patents must be protected.

\section{Judgment}

After analyzing, reporting on and discussing the proceedings, the Judges of the Supreme Federal Court agree, in accordance with the text of the judgment and the 
opinion of the reporting judge, Judge Dias Toffoli, by majority of votes, with the dissenting opinions of Judges Roberto Barroso and Luiz Fux (President), to uphold the direct action and the application for a declaration of unconstitutionality of the sole paragraph of Art. 40 of Law No. 9279/1996.

Furthermore, the Judges agree by a majority of votes, in accordance with the terms of the rapporteur, Judge Dias Toffoli, to modulate the effects of the decision declaring the sole paragraph of Art. 40 of the IPA unconstitutional, conferring it $\boldsymbol{e x}$ nunc effects as of the publication date of the text of this judgment so as to maintain the term extensions granted to patents on the basis of the legal provision and to preserve the validity of patents already granted and still unexpired due to the application of said legal provision. Exempted from modulation are: (i) the judicial actions filed by or on 7 April 2021 (date of the partial upholding of the preliminary injunction in the present case), and (ii) the patents granted with an extension of the term related to pharmaceutical products and processes, as well as healthcare devices and/or materials. In both cases an ex tunc effect applies, which will lead to the loss of the term extensions granted on the basis of the sole paragraph of Art. 40 of the IPA, respecting the validity period of patents laid down in Art. 40, caput of Law No. 9279/1996 and safeguarding possible concrete effects already produced due to the extension of the period of validity of the said patents. Judges Roberto Barroso and Luiz Fux (President) would modulate the effects of the decision to a greater extent; Judges Edson Fachin, Rosa Weber and Marco Aurélio dissent.

Publisher's Note Springer Nature remains neutral with regard to jurisdictional claims in published maps and institutional affiliations. 